\title{
Analyzing Proprietary Games Engines for Developing Educational and Serious Games
}

\author{
Humberto Marín-Vega ${ }^{1}$, Giner Alor-Hernandez ${ }^{1}$, Ramón Zatarain-Cabada ${ }^{2}$, \\ M. Lucía Barrón-Estrada ${ }^{2}$ \\ ${ }^{1}$ Instituto Tecnológico de Orizaba, Division of Research and Postgraduate Studies, \\ Mexico \\ ${ }^{2}$ Instituto Tecnológico de Culiacán, Division of Research and Postgraduate Studies, \\ Mexico \\ humbert_marin@outlook.com, galor@itorizaba.edu.mx, \\ \{rzatarain, lbarron\}@itculiacan.edu.mx
}

\begin{abstract}
Gamification is the use of game design elements to enhance the teaching-learning process; with gamification it is possible to make a routine nongame activity such into a game that is engaging and fun. Also serious games are proposed as a more efficient and enjoyable way to carry out cognitive assessment, the serious games combine a serious intention with game's rules and targets. This paper presents an analysis of the most used proprietary games engines in order to identify games and learning attributes supported for developing educational and serious games.
\end{abstract}

Keywords: Gamification, proprietary games engines, serious games.

\section{Introduction}

Gamification is the use of game mechanics and experience design to digitally engage and motivate people to achieve their goals [1]. Through gamification we can not only create a mindset that encourages students to try new things, to not be afraid of failing [2], but also can enable students to engage in enjoyable experiences for the purpose of learning. The gamification of learning is an educational approach to motivate students to learn by using video game design and game elements in learning environments. The gamification is today considered as an essential driver of innovation in this domain. Therefore, it is important to understand how Serious Games can best be designed and used as an environment for organizational learning [3]. Serious games are aimed at a population that is familiar with online games, particularly Generation Y, who are more playful, outgoing, are major consumers of training and coaching, and cannot be recruited in the same way as previous generations $[4,5]$. The advantage of serious games as a tool for learning is mainly based on the ability to balance entertainment, interactivity and replay ability of the typical games with the learning objectives of a specific educational goal. 
Proprietary game engines allow developing Web-based applications, native mobile and hybrid applications by using game strategies and techniques [6], There are several proprietary games engines and the selection process is a very difficult task, therefore the objective of this work is to provide support on the selection process of proprietary games engines depending on the educational activities to be considered in the development of an application. This paper presents an analysis of proprietary games engines by considering learning activities in order to provide a reference for choosing the most suitable games engine for the development of educational applications, serious games or both.

\section{State of the Art}

In recent years, several studies have been proposed with the aim of improving the development of educational games. Most of these research works have been focused on the use of gamification in a variety of contexts. In this section, we present a set of related works focused on the use of educational games, serious games and both. These works have been grouped according to the kind of application to be developed: 1) gamification applications, 2) serious games.

\subsection{Use of Gamification Techniques on Educational Applications}

Henzi \& Alt [7] applied gamification to leverage the use of information for informationintensive business tasks in the context of corporate intranets. It presents the results of an online experiment, which was conducted in the banking industry. Matallaoui, Herzig \& Zarnekow [8] proposed the Gamification Modeling Language initially as a formal language adhering to a context-free grammar and is based on the current consensus of game design elements that can be found in the gamification. Hamari, Koivisto \& Sarsa [9] defined gamification as an emerged means of supporting customer engagement and enhancing positive patterns in user service by using game mechanics in serious contexts. Ibañez, Di-Serio \& Delgado-Kloos [10] evaluated the learning effectiveness and engagement appeal of a gamified learning activity targeted at the learning of $\mathrm{C}$ programming language. The results of the evaluation show positive effects on the engagement of students toward the gamified learning activities and a moderate improvement in learning outcomes. Marti-Parreño, Segui-Mas \& Segui-Mas [11] carried out an exploratory study aims to gain a better knowledge of teachers' serving in higher education institutions attitude towards gamification. Actual use of gamification is also explored. Results show no differences in use of gamification by age, gender or type of institution (public or private). Long [12] designed and integrated gamification with an ITS to support students' learning of actionable rules for making problem selection decisions based on their learning status afforded by the Open Learner Model (OLM), while enhancing both their enjoyment and domain level learning with the ITS. González, Mora \& Toledo [13] presented a conceptual architecture proposal for an Intelligent Tutorial System (ITS) known as EMATIC (Mathematics Education through ICT) that includes gamification elements as key components of the system. Dermeval [14] the main challenge of this project was contributed to the actively participation of teachers in the use of gamified intelligent tutoring systems. 


\subsection{Use of Serious Games on Educational Applications}

Boughzala, Michel \& De-Freitas [15] defined that a Serious Game combines a serious intention with a game's rules and targets. Serious game often considered to be technological applications that use games to engage individuals in an experience through which a learning or professional training aim can be explored. Matallaoui, Herzig, \& Zarnekow [8] introduced a model-driven architecture for designing as well as generating building blocks for serious games. Sorensen \& Meyer [16] defined Serious Games as digital games that educate, train, and inform. These games are designed for a primary purpose other than entertainment, enjoyment or fun. The initial intention of serious games is to combine the serious aspects (learning, instruction, etc) with the playing aspect of digital games. Sorensen, b.H. \& Meyer [17] used the Serious games in language learning and teaching a theoretical perspective. On the other hand, Fong-Ling, Rong-Chang \& Sheng-Chin [18] designed the hands-on OS game to introduce learners the common problems associated with the operating system of the computer. The main goal of this game is to enhance the proficiency of the learner in certain skills related to computer's operating system. Martins, Carvalho \& Soares [19] proposed that one way to help both, professionals and patients, can be found in the development of serious games oriented to motor rehabilitation in physical therapy sessions. This work to present a modular system of Back Office, for centralized management of one or more games targeted for physical therapy.

\section{Proprietary Games Engines for Developing Educational and Serious Games}

A proprietary game engine is a software framework designed for the creation and development of video games. Currently, there are different games engines that allow the development of games able to be applied in a wide range of browsers and platforms from a single development in some cases [20]. The most commons proprietary game engines are:

- Unity is a games engine can handle, from a massively-multi player online game all the way down to a simple kart racer [21].

- CryEngine is a powerful real-time game development [22].

- Unreal engine 4 is a complete suite that offers a new workflow features and a deep toolset empower with a complete $\mathrm{C}++$ source code [23].

- Cocos2D is an open source cross-platform game framework written in C++/Javascript/Lua. [24].

- Blender is a fast, powerful, and free 3D graphics and animation tool. [25].

- BigWorld is used by developers to develop game logic and AI and is based on the Python scripting language. [26].

- Leadwerks is the easiest game engine to make 3D games powered by OpenGL 4.0 [27].

- HeroEngine is a 3D game engine and server technology platform for building MMO-style games [28]. 


\section{$4 \quad$ Learning Activities on Educational and Serious Games}

Gamification is the use of game mechanics and experience design to digitally engage and motivate people to achieve their goals. The application of gamification to real life tasks to influence behavior, improve motivation and enhance engagement [34]. From the innovation perspective, concepts such as serious gaming and gamification are the most interesting and valuable in this domain.

Lameras et al. [35] proposed a serious games classification based on the design features and learning properties learning of the game. The study provides guidance and support to teachers, trainers and game designers to design plan and use serious games for a topic or complete module. Lameras et al. [35] proposed the learning design as a fundamental mode in architecture game design. Learning attributes are proposed as collaborative learning, individual transmission of information and discussion and argument.

Based on the game attributes, Lameras [35] classified the games depending on their relevant attributes. Lameras realized an attempt to assign games categories understanding game attributes in the game that are used for creating instances of games attributes in the educational practice; for example, rules are made by scoring. Lameras proposed this classification because there was not a taxonomy to classify the attributes of the game in specific categories, the classification was done with the aim of helping game designers and instruction. The category, presented by Lameras, is described in the table 1, which is based according to the identification of the attributes of each kind of game:

Table 1. Game categories and associated game attributes.

\begin{tabular}{|c|c|c|}
\hline Game Cathegory & \multicolumn{2}{|c|}{ Game Attribute } \\
\hline Rules & $\begin{array}{ll} & \text { Scoring } \\
- & \text { Moving } \\
- & \text { Timers levels } \\
\end{array}$ & $\begin{array}{ll}\text { - } & \text { Progress bars } \\
\text { - Game instructions including } \\
\text { victory conditions }\end{array}$ \\
\hline Goals and Choices & $\begin{array}{ll}- & \text { Game journal } \\
- & \text { Missions } \\
\text { - } & \text { Objective cards } \\
\text { - } & \text { Storytelling } \\
\end{array}$ & $\begin{array}{ll} & \text { Nested dialogues } \\
- & \text { Puzzles } \\
- & \text { NPCs / avatars } \\
\end{array}$ \\
\hline Tasks / challenges & $\begin{array}{ll}\text { - } & \begin{array}{l}\text { NPC-based } \\
\text { description }\end{array} \\
\text { - } & \text { Progress bars } \\
\text { - } & \text { Multiple choices to select } \\
\text { - } & \text { Major tasks } \\
\end{array}$ & $\begin{array}{ll}\text { - } & \text { Puzzles } \\
\text { - } & \text { Research points } \\
\text { - } & \text { Study } \\
\text { - } & \text { Requirements } \\
\text { - } & \text { Branch tasks } \\
\end{array}$ \\
\hline $\begin{array}{l}\text { Collaboration and } \\
\text { competition }\end{array}$ & $\begin{array}{ll}- & \text { Role-playing } \\
\text { - } & \text { Community collaboration } \\
\text { - } & \text { Epic meaning } \\
\text { - } & \text { Bonuses } \\
\text { - } & \text { Contest }\end{array}$ & $\begin{array}{ll} & \text { Timers } \\
- & \text { Coins } \\
- & \text { Inventories } \\
- & \text { Leader boards } \\
- & \text { Communal discovery } \\
- & \text { Scoring } \\
\end{array}$ \\
\hline Feedback / assessment & $\begin{array}{ll}\text { - } & \text { Game hints, NPCs } \\
\text { - } & \text { Game levels } \\
\text { - } & \text { Gaining/loosing lives } \\
\text { - } & \text { Progress bars } \\
\text { Dashboards }\end{array}$ & $\begin{array}{l}\text { - Lives/virtual currencies to be } \\
\text { used for buying game items } \\
\text { from an online inventory } \\
\text { Progress trees }\end{array}$ \\
\hline
\end{tabular}




\section{Analysis of Proprietary Games Engines for Developing Educational and Serious Games}

An analysis of proprietary games engines for game development is presented in this section. In order to validate the aforementioned analysis, we have selected ten proprietary games engines. Proprietary games engines selected allow developing Web application, mobile applications and hybrid applications in some cases. The proprietary games engines selected were: Unity, CryEngine, Unreal engine 4, $\operatorname{cocos} 2 \mathrm{D}$, Blender, BigWorld, Leadwerks and HeroEngine. There are the most popular proprietary games engines in use by developers, because every proprietary games engine selected provide a suite of visual development tools, in addition to reusable software components. At the end of the analysis process, we have determined the importance of the game attributes for the educational context and the availability of each game attributes on a game categories according to the selected proprietary games engines. Nonetheless, it is possible that, according to the type of educational game and the academic level to which this educational game is aimed, some other attributes can be required that they may have been omitted in this evaluation.

Table 2. Analysis of proprietary games engines.

\begin{tabular}{|c|c|c|c|c|c|}
\hline \multicolumn{6}{|c|}{ Game Attribute } \\
\hline Game engines & Rules & $\begin{array}{c}\text { Goals and } \\
\text { Choices }\end{array}$ & $\begin{array}{c}\text { Task/ } \\
\text { Challenges }\end{array}$ & $\begin{array}{c}\text { Collaboration } \\
\text { and } \\
\text { competition }\end{array}$ & $\begin{array}{l}\text { Feedback / } \\
\text { Assessment }\end{array}$ \\
\hline Unity & $\begin{array}{l}\text {-Scoring } \\
\text {-Moving } \\
\text {-Timers } \\
\text { levels } \\
\text {-Progress } \\
\text { bars } \\
\text {-Game } \\
\text { instructions } \\
\text { including } \\
\text { victory } \\
\text { conditions } \\
\end{array}$ & $\begin{array}{l}\text {-Game } \\
\text { journal } \\
\text {-Missions } \\
\text {-Objective } \\
\text { cards } \\
\text {-Storytelling } \\
\text {-nested } \\
\text { dialogues } \\
\text {-Puzzles } \\
\text {-NPCs }\end{array}$ & $\begin{array}{l}\text {-Progress bars } \\
\text {-Multiple } \\
\text { choices to } \\
\text { select } \\
\text {-Major taks } \\
\text {-Branch task } \\
\text {-Puzzles } \\
\text {-Research } \\
\text { points } \\
\text { - } \\
\text { Requirements }\end{array}$ & $\begin{array}{l}\text {-Role playing } \\
\text {-Community } \\
\text { collaboration } \\
\text {-Bonuses } \\
\text {-Contest } \\
\text {-Scoring } \\
\text {-Timers } \\
\text {-Coins } \\
\text {-Inventories } \\
\text {-Leader boards }\end{array}$ & $\begin{array}{l}\text {-Game hints } \\
\text {-NPCs } \\
\text {-Game levels } \\
\text {-Gaining/ } \\
\text { loosing lives } \\
\text {-Progress } \\
\text { bars } \\
\text {-Dashboards } \\
\text {-Lives. }\end{array}$ \\
\hline Cryengine & $\begin{array}{l}\text {-Moving } \\
\text {-Timers } \\
\text { levels } \\
\text {-Progress } \\
\text { bars } \\
\text {-Game } \\
\text { instructions } \\
\text { including } \\
\text { victory } \\
\text { conditions } \\
\end{array}$ & $\begin{array}{l}\text {-Missions } \\
\text {-Objective } \\
\text { cards } \\
\text {-Puzzles } \\
\text {-NPCs/ } \\
\text { Avatars }\end{array}$ & $\begin{array}{l}\text {-Progress bars } \\
\text {-Multiple } \\
\text { choices to } \\
\text { select } \\
\text {-Puzzles } \\
- \\
\text { Requirements }\end{array}$ & $\begin{array}{l}\text {-Bonuses } \\
\text {-Contest } \\
\text {-Scoring } \\
\text {-Timers } \\
\text {-Coins } \\
\text {-Leader boards }\end{array}$ & $\begin{array}{l}\text {-Game hints } \\
\text {-NPCs } \\
\text {-Game levels } \\
\text {-Progress } \\
\text { bars } \\
\text {-Dashboards }\end{array}$ \\
\hline $\begin{array}{c}\text { Unreal } \\
\text { Engine } 4\end{array}$ & $\begin{array}{l}\text {-Scoring } \\
\text {-Moving } \\
\text {-Timers } \\
\text { levels } \\
\text {-Progress } \\
\text { bars } \\
\text {-Games } \\
\text { instructions }\end{array}$ & $\begin{array}{l}\text {-Game } \\
\text { journal } \\
\text {-Missins } \\
\text {-Objective } \\
\text { cards } \\
\text {-Storytelling } \\
\text {-Puzzles }\end{array}$ & $\begin{array}{l}\text {-Progress bars } \\
\text {-Multiple } \\
\text { choices to } \\
\text { select } \\
\text {-Major tasks } \\
\text {-Branch task } \\
\text {-Puzzles }\end{array}$ & $\begin{array}{l}\text {-Role playing } \\
\text {-Community } \\
\text { collaboration } \\
\text {-Bonuses } \\
\text {-Contest } \\
\text {-Scoring } \\
\text {-Timers } \\
\text {-Coins } \\
\end{array}$ & $\begin{array}{l}\text {-Game hints } \\
\text {-NPCs } \\
\text {-Game levels } \\
\text {-Gaining/ } \\
\text { loosing lives } \\
\text {-Progress } \\
\text { bars }\end{array}$ \\
\hline
\end{tabular}


Humberto Marín-Vega, Giner Alor-Hernandez, Ramón Zatarain-Cabada, M. Lucía Barrón-Estrada

\begin{tabular}{|c|c|c|c|c|c|}
\hline \multicolumn{6}{|c|}{ Game Attribute } \\
\hline Game engines & Rules & $\begin{array}{l}\text { Goals and } \\
\text { Choices }\end{array}$ & $\begin{array}{c}\text { Task/ } \\
\text { Challenges }\end{array}$ & $\begin{array}{c}\text { Collaboration } \\
\text { and } \\
\text { competition }\end{array}$ & $\begin{array}{l}\text { Feedback / } \\
\text { Assessment }\end{array}$ \\
\hline & $\begin{array}{l}\text { including } \\
\text { victory } \\
\text { conditions. }\end{array}$ & $\begin{array}{l}\text {-NPCs/ } \\
\text { Avatars }\end{array}$ & $\begin{array}{l}\text {-Research } \\
\text { points } \\
\text { - } \\
\text { Requirements }\end{array}$ & $\begin{array}{l}\text {-Inventories } \\
\text {-Leader boards } \\
\text {-Communal } \\
\text { discovery. }\end{array}$ & $\begin{array}{l}\text {-Progress } \\
\text { trees. }\end{array}$ \\
\hline $\operatorname{Cocos} 2 d$ & $\begin{array}{l}\text {-Scoring } \\
\text {-Moving } \\
\text {-Timers } \\
\text { levels } \\
\text {-Progress } \\
\text { bars } \\
\text {-Game } \\
\text { instructions } \\
\text { including } \\
\text { victory }\end{array}$ & $\begin{array}{l}\text {-Game } \\
\text { journal } \\
\text {-Missions } \\
\text {-Objective } \\
\text { cards } \\
\text {-Puzzles } \\
\text {-NPCs/ } \\
\text { avatars }\end{array}$ & $\begin{array}{l}\text {-NPCs-based } \\
\text { tasks } \\
\text { description } \\
\text {-Multiple } \\
\text { choices to } \\
\text { select } \\
\text {-Major tasks } \\
\text {-Branch tasks } \\
\text {-Puzzles } \\
\text {-Research } \\
\text { points } \\
\text {-Requiremets }\end{array}$ & $\begin{array}{l}\text {-Role playing } \\
\text {-Community } \\
\text { collaboration } \\
\text {-Bonuses } \\
\text {-Contest } \\
\text {-Scoring } \\
\text {-Timers } \\
\text {-Coins } \\
\text {-Inventories } \\
\text {-Leader boards. }\end{array}$ & $\begin{array}{l}\text {-Game hints } \\
\text {-NPCs } \\
\text {-Game levels } \\
\text {-Gaining/ } \\
\text { loosing lives } \\
\text {-Progress } \\
\text { bars } \\
\text {-Dashboards } \\
\text {-Progress } \\
\text { trees. }\end{array}$ \\
\hline Blender & $\begin{array}{l}\text {-Scoring } \\
\text {-Moving } \\
\text {-Timers } \\
\text { levels } \\
\text {-Progress } \\
\text { bars } \\
\text {-Game } \\
\text { instructions. } \\
\text { Including } \\
\text { victory }\end{array}$ & $\begin{array}{l}\text {-Missions } \\
\text {-Objective } \\
\text { cards } \\
\text {-NPCs/ } \\
\text { avatars. }\end{array}$ & $\begin{array}{l}\text {-Progress bars } \\
\text {-Major tasks } \\
\text {-Branch tasks } \\
\text {-Puzzles }\end{array}$ & $\begin{array}{l}\text {-Bonuses } \\
\text {-Contest } \\
\text {-Scoring } \\
\text {-Timers } \\
\text {-Coins } \\
\text {-Leader boards }\end{array}$ & $\begin{array}{l}\text {-Game hints } \\
\text {-NPCs } \\
\text {-Game levels } \\
\text {-Progress } \\
\text { bars } \\
\text {-Dashboards } \\
\text {-Progress } \\
\text { trees }\end{array}$ \\
\hline BigWorld & $\begin{array}{l}\text {-Scoring } \\
\text {-Moving } \\
\text {-Timers } \\
\text { levels } \\
\text {-Progress } \\
\text { bars } \\
\text {-Game } \\
\text { instructions } \\
\text { including } \\
\text { victory } \\
\text { conditions. }\end{array}$ & $\begin{array}{l}\text {-Game } \\
\text { journal } \\
\text {-Missions } \\
\text {-Objective } \\
\text { cards } \\
\text {-Puzzles } \\
\text {-NPCs/ } \\
\text { avatars. }\end{array}$ & $\begin{array}{l}\text {-NPCs-based } \\
\text { task } \\
\text { description } \\
\text {-Progress bars } \\
\text {-Multiple } \\
\text { choices to } \\
\text { select } \\
\text {-Major tasks } \\
\text {-Branch tasks } \\
\text {-Puzzles } \\
\text {-Research } \\
\text { points } \\
\text { - } \\
\text { Requirements } \\
\end{array}$ & $\begin{array}{l}\text {-Role-playing } \\
\text {-Community } \\
\text { collaboration } \\
\text {-Bonuses } \\
\text {-Contest } \\
\text {-Scoring } \\
\text {-Timers } \\
\text {-Coins } \\
\text {-Inventories } \\
\text {-leader boards. }\end{array}$ & $\begin{array}{l}\text {-Game hints } \\
\text {-NPCs } \\
\text {-Gaining/ } \\
\text { loosing lives } \\
\text {-Progress } \\
\text { bars } \\
\text {-Dashboards } \\
\text {-Progress } \\
\text { trees. }\end{array}$ \\
\hline Leadwerks & $\begin{array}{l}\text {-Scoring } \\
\text {-Moving } \\
\text {-Timers } \\
\text { levels } \\
\text {-Progress } \\
\text { bars. }\end{array}$ & $\begin{array}{l}\text {-Game } \\
\text { journal } \\
\text {-Missions } \\
\text {-Puzzles } \\
\text {-NPCs/ } \\
\text { avatars }\end{array}$ & $\begin{array}{l}\text {-Progress bars } \\
\text {-Multiple } \\
\text { choices to } \\
\text { select } \\
\text {-Major tasks } \\
\text {-Branch tasks } \\
\text {-Puzzles. }\end{array}$ & $\begin{array}{l}\text {-Role-playing } \\
\text {-Community } \\
\text { collaboration } \\
\text {-Bonuses } \\
\text {-Scoring } \\
\text {-Timers } \\
\text {-Coins } \\
\text {-Inventories } \\
\text {-Leader boards }\end{array}$ & $\begin{array}{l}\text {-Game hints } \\
\text {-NPCs } \\
\text {-Game levels } \\
\text {-Gaining/ } \\
\text { loosing lives } \\
\text {-Progress } \\
\text { bars } \\
\text {-Dashboards. }\end{array}$ \\
\hline HeroEngine & $\begin{array}{l}\text {-Scoring } \\
\text {-Moving } \\
\text {-Timers } \\
\text { levels }\end{array}$ & $\begin{array}{l}\text {-Game } \\
\text { journal } \\
\text {-Missions }\end{array}$ & $\begin{array}{l}\text {-Progress bars } \\
\text {-Major tasks } \\
\text {-Branch tasks } \\
\text {-Puzzles }\end{array}$ & $\begin{array}{l}\text {-Role playing } \\
\text {-Bonuses } \\
\text {-Scoring } \\
\text {-Timers }\end{array}$ & $\begin{array}{l}\text {-Game hints } \\
\text {-NPCs } \\
\text {-Game levels }\end{array}$ \\
\hline
\end{tabular}




\begin{tabular}{llllll}
\hline Game engines & Rules & $\begin{array}{c}\text { Goals and } \\
\text { Choices }\end{array}$ & $\begin{array}{c}\text { Task/ } \\
\text { Challenges }\end{array}$ & $\begin{array}{c}\text { Collaboration } \\
\text { and } \\
\text { competition }\end{array}$ & $\begin{array}{l}\text { Feedback / } \\
\text { Assessment }\end{array}$ \\
\hline & -Progress & -Objective & - & -Coins & -Progress \\
& bars & cards & Requirements. & $\begin{array}{l}\text {-Inventories } \\
\text { bars }\end{array}$ \\
& -Puzzles & & -Leader boards. & -Dashboards \\
& -NPC & & & -Progress \\
& & & & trees. \\
\hline
\end{tabular}

The goal of the analysis is to provide a reference for choosing the most suitable games engine for the development of educational or serious games considering learning activities and the game attributes that can be present in the application.

\section{Conclusions and Future Directions}

Gamification is the use of gaming principles in the field of education in order to get students involved, engaged, and excited about learning. Gamification is used in several different contexts, this work demonstrates the utility and importance of the game attribute in the educational environment as well. Meanwhile, Serious games are virtual environments explicitly intended to educate or train, there are designed for a primary purpose other than pure entertainment. As future direction, the inclusion of additional framework such as Cube, adventure game studio, to mention but a few, will be considered. Also we will consider the inclusion or approach of a methodology to analysis of games engines for educational and serious games.

Acknowledgments. This work was supported and sponsored by the Tecnológico Nacional de México (TecNM), National Council of Science and Technology (CONACYT) and the Public Education Secretary (SEP) through PRODEP.

\section{References}

1. Burke, B.: Gartner Redefines Gamification. http://blogs.gartner.com/brian_burke/2014/04/ 04/gartner-redefines-gamification (2014)

2. Chung-Ho, S., Ching-Hsue, C.: A Mobile Game-based Insect Learning System for improving the learning achievements. Procedia - Social and Behavioral Sciences, no.103 pp. 42-50 (2013)

3. Boughzala, I., Michel, H., de Freitas, S.: Introduction to the Serious Games, Gamification and Innovation Minitrack. In: 48th Hawaii International Conference on System Sciences, IEEE Computer Society, pp. 625 (2015)

4. Morley, C., Figueiredo, M., Baudoin, E., Salierno, A.: La génération y dans l'entreprise: mythes et réalités. Paris, Pearson (2012)

5. Twenge, J. M., Campbell, S. M., Hoffman, B. J., Lance, C. E.: Generational differences in work values: Leisure and extrinsic values increasing, social and intrinsic values decreasing. Journal of Management, 36(5), pp. 1117-1142 (2010)

6. Nagle, D.: HTML5 Game Engines: App Development and Distribution. pp. 41-43 (2014) 
7. Benedikt, M., Henzi, C., Alt, R.: Increasing intranet usage through gamification-insights from an experiment in the banking industry. In: 48th International Conference on System Sciences, Hawaii, IEEE Computer Society, pp. 625-642 (2015)

8. Matallaoui, A., Philipp, H., Rüdiger, Z.: Model-Driven Serious Game Development: Integration of the Gamification Modeling Language GaML with Unity. In: 48th Hawaii International Conference on System Sciences, Hawaii, IEEE (2015)

9. Hamari, J., Koivisto, J., Sarsa, H.: Does gamification work? A literature review of empirical studies on gamification. In: Proc. 47th Hawaii Int. Conf. Syst. Sci., pp. 1-10 (2014)

10. Ibañez, M. B., Di-Serio, A., Delgado-Kloos, C.: Gamification for Engaging Computer Science Students in Learning Activities: A Case Study. IEEE Transactions on learning technologies, 7(3), pp. 291-301 (2014)

11. Marti-Parreño, J., Segui-Mas, D., Segui-Mas, E.: Teachers' Attitude towards and Actual Use of Gamification. In: 2nd International Conference on Higher Education Advances, Valencia, España, Elsevier, pp. 682-688 (2016)

12. Long, Y.: Gamification of Support for Learning Effective Problem Selection Strategies in Intelligent Tutoring Systems. Human Computer Interaction Institute, Pittsburgh, Carnegie Mellon University (2014)

13. González, C., Mora, A., Toledo, P.: Gamification in intelligent tutoring systems. Research gate (2014)

14. Dermeval, D.: Intelligent Authoring of Gamified Intelligent Tutoring Systems. In: Proceedings of the 24th ACM Conference on User Modeling, Adaptation and Personalisation (UMAP 2016), Halifax, Canada, ACM (2016)

15. Sorensen, B. H., Meyer, B.: Serious games in language learning and teaching-a theoretical perspective. In: Proceedings of the 2007 Digital Games research Association Conference, pp. 559-566 (2007)

16. Fong-Ling, F., Rong-Chang, S., Sheng-Chin, Y.: EGameFlow: A scale to measure learners' enjoyment of e-learning games. Computers \& Education, 52, pp. 101-112 (2009)

17. Tiago, M., Carvalho, V., Soares, F.: Web Platform for Serious Games' Management. Procedia Computer Science, 64, pp. 1115-1123 (2015)

18. Creighton, R. H.: Unity 3D Game Development by Example. Toronto, Packt Publishing (2010)

19. Corporation, V.: CRYENGINE. Animación y modelado, Available: http://store. steampowered.com/app/220980/?1=spanish (2016)

20. Games, E.: Unreal engine. Unreal engine 4, Avaliable: https://www.unrealengine.com/ unreal-engine-4 (2016)

21. Cocos: Cocos2D. Avaliable: http://www.cocos2d.org (2016)

22. Wartmann, C.: Blender Book: Free 3D Graphics Software for the Web and Video. Vol. 1, Starch Press (2011)

23. Pty, B.: Server Programming Guide. Australia, BigWorld Pty Ltd, (2012)

24. Corporation, V.: Leadwerks Game Engine. Avaliable: http://store.steampowered. com/app/251810 (2016)

25. Fabrik, I.: HeroEngine. Avaliable: http://www.heroengine.com (2016)

26. Burke, B.: Gartner Redefines Gamification. Avaliable: http://blogs.gartner.com/brian_ burke/2014/04/04/gartner-redefines-gamification (2014)

27. Lameras, P.: Essential Features of Serious Games Design in Higher Education. Society for research into higher education, pp. 3-22 (2015)

28. McLean, P., Scott, B.: Competencies for Learning Design: A Review of the Literature and a Proposed Framework. British Journal of Educational Technology, 42(4), pp. 557-572 (2011) 
Analyzing Proprietary Games Engines for Developing Educational and Serious Games

29. Beetham, H.: Review: Design for learning programme phase 2. Review of learning design as part of the JISC's Design for Learning programme, Available: http://www.jisc.ac.uk/ whatwedo/programmes/elearningpedagogy/designlearn.a spx (2008) 